\title{
China, Climate Change and the Arctic Environment
}

\section{Kopra, Sanna}

Brill

2020-03

Kopra , S , Hurri , K , Kauppila , L , Stepien , A \& Yamineva , Y 2020 , China, Climate

Change and the Arctic Environment . in T Koivurova \& S Kopra (eds), Chinese Policy and

Presence in the Arctic . Brill , pp. 62-89.

http://hdl.handle.net/10138/328102

unspecified

acceptedVersion

Downloaded from Helda, University of Helsinki institutional repository.

This is an electronic reprint of the original article.

This reprint may differ from the original in pagination and typographic detail.

Please cite the original version. 


\section{China and the Arctic environment}

Chapter 5. China, climate change and the Arctic environment

Sanna Kopra, Karoliina Hurri, Liisa Kauppila, Adam Stepien, and Yulia Yamineva

In: Timo Koivurova \& Sanna Kopra (eds.) Chinese policy and present in the Arctic. Leiden: Brill Publishing.

\subsection{Introduction}

In recent decades, the Arctic region has faced major environmental changes. In particular, there is growing scientific evidence that Arctic climate change is proceeding much faster than expected earlier: the Arctic Ocean may be ice-free in summer as early as the late 2030s (AMAP, 2017: 3). At the same time, the melting of ice and permafrost in the High North is accelerating climate change and altering ecosystems globally, including in China (ACIA, 2004; AMAP, 2017). Climate change is a complex global problem that cannot be solved through regional actions by Arctic states and hence, global efforts are necessary to respond to climate change. China, the world's biggest greenhouse gas (GHG) emitter, plays a crucial role in those efforts - without its participation, any effort to prevent dangerous climate change from happening will fail. For China, climate change is also an important driver of the state's Arctic engagement: the Chinese government argues that due to the adverse effects of climate change, it has special interests in the Arctic and it must have a chance to be involved in Arctic governance. In this chapter, we investigate China's role and interests in international climate politics, and discuss their implications for the Arctic. We offer a short historical overview of China's role in the United Nations (UN) negotiations on climate change as well as its domestic climate mitigation policies. Since the very beginning in the late 1980s, China has taken an active part - if not always with enthusiasm - in international negotiations on climate change. Today, China is party to the United Nations Framework Convention on Climate Change (UNFCCC), the Kyoto Protocol, and the Paris Agreement, which establish the keystones of international climate regime. In addition, we study the extent to which China's Arctic policy addresses climate change. We also take a look at China's broader ecological footprint in the High North. 


\section{China and the Arctic environment}

\subsection{China's contribution to Arctic environmental change}

Today, it is evident that human activities such as burning fossil fuels have increased the concentration of greenhouse gas emissions in the atmosphere and hence caused climate change (Intergovernmental Panel on Climate Change, 2014). In October 2018, the Intergovernmental Panel on Climate Change made very clear that to prevent the most dangerous climate change from happening, we must reduce global net carbon dioxide (CO2) emissions from 2010 levels by 45 percent before 2030 (Intergovernmental Panel on Climate Change, 2018). Although only a small proportion of global greenhouse gas emissions originate in the Arctic, the region has emerged as a showcase of global warming and its impacts. In the Arctic, temperatures have risen more rapidly than in any other region on earth during the last 30 years. As a result, sea ice, permafrost and snow cover have decreased dramatically, which hampers the livelihoods of local people and threatens the survival of many Arctic species such as the polar bear, the walrus and the seal, for instance (see, for example, ACIA, 2004; AMAP, 2017; Serreze, 2018). Arctic environmental change also has significant global impacts, and it may have an influence on Southeast Asian monsoon and winter haze in China, for instance (ibid.; Wang, Chen \& Liu, 2015.). At the same time, the warming climate brings new economic opportunities for resource exploitation, fisheries, shipping, and tourism - further intensifying the already high pressure on the Arctic environment.

In line with China's rapid economic growth, its total greenhouse gas emissions have grown at extraordinary speed during the past couple of decades. Between 1990 and 2013, China's carbon dioxide emissions increased by 80 percent (Olivier et al., 2015: 10). In brief, China's total energy consumption and carbon dioxide emissions started to grow significantly from 2001 onwards when China joined the World Trade Organization, which directed the nation towards heavy and chemical industries instead of centralizing to modern technologies (Chen, 2012). China's emissions also grew because of huge infrastructure projects such as the Three Gorges Dam (ibid.). Today, China is the world's biggest contributor to climate change - in 2017, its greenhouse gas emissions accounted for 27 percent of global emissions (Olivier \& Peters, 2018). In terms of per capita emissions, however, China's emissions are much lower than those of the United States, Canada and the Arab states of the Persian Gulf, for example (EDGAR, 2017). In addition, China's non- 


\section{China and the Arctic environment}

$\mathrm{CO} 2$ emissions, ${ }^{1}$ especially methane and hydrofluorocarbons (HFCs), are high and are projected to nearly double by 2030 under existing policies (Yao et al., 2016).

China further impacts global and regional climate change through its emissions of black carbon. Black carbon, which also contributes to air pollution, has recently emerged as a key climate-warming agent and is as such referred to as one of the short-lived climate pollutants $\left(\mathrm{SLCPs}^{2}\right)$ (Bond et al., 2013). It is formed as a result of the incomplete combustion of fossil fuels and biomass, and co-emitted with GHGs and other aerosols. Black carbon accelerates global warming directly and indirectly through reducing the albedo effect (the ability to reflect sunlight) of the surface of the earth. Its emissions have a stronger warming effect on glaciated regions including the Arctic (AMAP, 2015: 9), where about 20-25 percent of warming and snow-ice cover loss is attributed to the reduction of the albedo effect caused by black carbon (Koch et al., 2011). China's emissions of black carbon have been estimated at 20-24 percent of global emissions for the period of 1990-2007 (UNEP, 2015: 11); however, these emissions reportedly fell by 27 percent in 2010-2017 due to pollution reduction policies (Zheng et al., 2018). Using biomass, coal or oil for cooking and heating in residential and industrial sectors as well as the use of diesel fuel for transportation are the main causes of black carbon emissions in China (Zheng et al., 2018). It has been shown that two-thirds of black carbon's warming effects in the Arctic come from non-Arctic countries (AMAP, 2015: 9), which highlights the role of China's emissions in Arctic warming. China's role in driving climate change through its emissions of long-lived GHGs and SLCPs is part of the country's broader environmental footprint in the Arctic. China is a source of a variety of pollutants (e.g. persistent organic pollutants and mercury) reaching the Arctic, and Chinese policies aimed at controlling such pollutants - if implemented effectively - benefit the Arctic environment. The picture of Chinese environmental footprint is complemented by the more direct impacts, namely through Chinese investments in Arctic locations. Moreover, China has an indirect influence on the Arctic environment and Arctic communities via driving the demand for Arctic resources and actions, such as contracts with Arctic states, aimed at securing China's access to these resources.

1 The remaining GHGs covered by the Kyoto Protocol include: methane $(\mathrm{CH} 4)$, nitrous oxide (N2O), hydrofluorocarbons (HFCs), perfluorocarbons (PFCs), sulfur hexafluoride (SF6), and nitrogen trifluoride (NF3).

2 Others include methane, tropospheric ozone and some hydrofluorocarbons. 


\section{China and the Arctic environment}

Persistent organic pollutants (POPs) and other long-range pollutants such as mercury can be transported by wind or ocean currents into the Arctic. POPs are deposited in the tissue of animals and humans and have noticeable health implications, especially in utilizing traditional sources of food (AMAP, 2009a; 2009b). While the global emissions of some POPs have decreased significantly, partly due to the adoption of the Stockholm POPs Convention ${ }^{3}-$ ratified by China in 2004 - other pollutants are still of major concern.

It is very difficult to assess the amount of pollution coming to the Arctic specifically from China. However, a few examples of the level of impact referring to East Asia or Asia (with China clearly the largest contributor due to the size of its manufacturing sector) can be given (data for 2000-2014). South-Eastern Asia is responsible for 12\% of HCB (hexachlorobenzene) depositions over the Arctic (compared to a contribution of $35 \%$ by the European continent), and East Asia is a source region for $11 \%$ of sulfur dioxide (SO2) and $21 \%$ of nitrogen oxides (NOx) depositions. Lindane $(\mathrm{y}-\mathrm{HCH})$ pollution reaching the Arctic from outside of the region comes mainly from China, which is responsible for $59 \%$ of global emissions. Brominated flame retardants (BFRs) come to the Arctic primarily from Asia (69\% of depositions in the Arctic) (Cavalieri et al., 2010).

According to Travnikov (2005), "about half the mercury deposition to the Arctic is due to the atmospheric transport from anthropogenic emission sources, of which the greatest contribution is made by Asian (33\%) and European sources (22\%)". South-East Asia is responsible for 39\% of global mercury emissions (equal to 685-1430 tonnes of mercury) (UNEP, 2018). The recently adopted Minamata Mercury Convention ${ }^{4}$ - ratified by China in 2016 - gives hope for the gradual decrease in the presence of mercury in the environment; however, the effects will be visible only in the long-term.

Historically, a crucial pollutant impacting the Arctic - and to a much greater extent, the Antarctic - were ozone-depleting substances (ODSs), in particular chlorofluorocarbons (CFCs). Following the entry into adoption (1982) and entry into force (1989) of the Montreal Protocol, global emissions of CFCs have fallen significantly. However, emissions of trichlorofluoromethane (CFC-11), the second-most abundant CFC, began to rise after 2012. According to recent findings,

3 The Stockholm Convention on Persistent Organic Pollutants, 23 May 2001, in force 17 May 2004, 40 ILM 532 (2001).

${ }^{4}$ Minamata Convention on Mercury, 19 January 2013, in force 16 August 2017, 55 ILM 582 (2016). 


\section{China and the Arctic environment}

one of the key sources of new emissions is probably located in North-East China (likely due to foam production) (Rigby et al., 2019).

An environmental issue currently in focus in the Arctic is pollution with marine litter primarily plastics - and microplastics. Sources of plastic in the Arctic Ocean include shipping, fisheries, Arctic rivers, as well as long-range transport via sea currents. Due to limited inflow of waters from the Pacific Ocean via cold currents passing the Bering Strait, Chinese litter sources are of secondary importance for the Arctic Ocean (PAME, 2019). However, microplastics may be airborne and transported long distances (Allen et al., 2019) and thus, China may constitute an important source of such airborne pollutants.

Apart from pollutants emitted within China's territory - and policies aimed at controlling these pollutants - China and Chinese economic operators may affect Arctic habitats in a more direct manner through the investments of Chinese companies in Greenland, northern Canada or Siberia, for example. Chinese demand for resources is a key contributor to the extractive industries investment potential in the Arctic. For instance, in 2013, China imported more than 60\% within the international iron ore trade, and the country accounted for $44 \%$ of global nickel demand in 2011. China is also a major and growing market for pulp derived from boreal forests. Moreover, Chinese shipping activities have marine and air quality impacts in the Arctic, which are bound to increase with the growing presence of Chinese vessels in the Arctic Ocean and adjacent waters.

In contrast to the European Union, which has attempted to assess its environmental footprint on the Arctic region (Cavalieri et al., 2010), China has thus far not undertaken such an evaluation.

\subsection{China's national goals and environmental challenges in a nutshell}

China is a one-party state without such democratic institutions as general elections. This does not, however, mean that the Chinese government can overlook the needs of its citizens. In other words, Chinese leaders must consider the question of legitimacy - the right to rule the country - in its decision-making. In practice, this means that the government's policies must address the key concern of the Chinese people, which arguably is the maintaining of social stability (see, for example, Kopra \& Kauppila, 2018; cf. Kallio, 2016). Ever since the beginning of the Reform and Opening Up period (gaige kaifang 改革开放) in 1978, one of the core prerequisites for reaching 


\section{China and the Arctic environment}

social stability has been material well-being - the sufficient wealth and health of Chinese people. For this reason, maintaining rapid economic growth has been a core priority of the Chinese government for the past forty years. As a consequence, China has lifted millions of people out of absolute poverty and has simultaneously become the world's second-largest economy, with a nominal gross domestic product (GDP) of USD13,616 billion in 2018, with continued $6.6 \%$ yearon-year growth (National Bureau of Statistics China, 2019).

The Chinese growth story is remarkable on both national and global scales, but it has also made the country's carbon dioxide emissions the highest in the world and created severe environmental problems domestically. The country's rapid industrialization has been a doubleedged sword, as providing material well-being through improved standards of living and employment, the high GDP share of the manufacturing sector (29\% in 2017) (World Bank, 2019) has also contributed negatively to the state of the country's environment. Furthermore, the growth of heavy industry in particular has been largely fueled by coal, whose largest global producer and consumer is China. In 2018, the industrial sector's overall contribution continued to account for approximately 34\% of the GDP (National Bureau of Statistics China, 2019), despite the fact that China's new economic policy is to shake off the status of being the "world's factory" and to prioritize quality over quantity through the Made in China strategy (State Council of the People's Republic of China, 2015). In addition, unbalanced and fast-paced urbanization has further deteriorated the environment by creating some of the world's most polluted megacities.

Given the structure of the country's economy and considerable population of 1.4 billion people, it is clear that China's energy demand is equally vast. Despite recent investments in renewable energy, energy production continues to be a key source of China's carbon emissions. At present, coal accounts for around 59 percent of the country's energy mix (National Bureau of Statistics of China, 2019), causing severe environmental degradation around the country. Given the fact that not only the air but also water and soil are largely contaminated by decades of burning coal (among other factors), Chinese people have been exposed to various kinds of pollution-related health problems, varying from respiratory to cardiovascular and mental health issues (e.g. Liu, Xu \& Yang, 2018). Indeed, numerous scientific studies have shown that fine particulate matter (PM2.5) causes adverse environmental and health impacts in China. In 2010, a million premature deaths in China annually were attributed to air pollution (Gu et al., 2018). A growing awareness of this linkage between pollution and personal health and wellbeing has provoked numerous 


\section{China and the Arctic environment}

pollution-related riots and demonstrations across China, (see, for example, Albert \& Xu, 2016; Babones, 2017; Kennedy, 2012) to an extent that is hard to estimate in the absence of trustworthy and transparent reporting.

Since the early 2000s, thus, it has became increasingly clear that the government's pursuit to build a harmonious society (hexie shehui 和谐社会) will not be successful without paying more attention to environmental protection (e.g. Pan, 2006). In 2007, then-President Hu Jintao officially proposed the building of an ecological civilization (shengtai wenming 生态文明) as a new guideline for the building up of a moderately well-off society. Although Hu did not offer a clear definition of the concept, his report to the 17th National Congress of the Communist Party of China indicated that the government had redefined its development model by putting more emphasis on sustainable development ( $\mathrm{Hu}, 2007)$. The concept of an ecological civilization was quickly incorporated into the government's overall policy plans, and it was added to the Constitution of the Communist Party of China in 2012 (the 18th National Congress of the Communist Party of China, 2012). This development put the Chinese government in a position in which it must increasingly find a balance between maintaining steady economic growth and reducing the health impacts of pollution and other environmental hazards and catastrophes affecting China.

It is clear that there are strong domestic incentives for China to decrease the use of coal in order to improve air quality and public health, and such reductions undoubtedly decrease both GHGs and air pollutant emissions as well. To some extent, the Chinese government's participation in the pioneering Arctic liquefied natural gas (LNG) project in Northern Siberia's Yamal Peninsula can also be connected to this trend: LNG is viewed as a rising, greener alternative to coal burning. The Arctic region is estimated to possess $30 \%$ of the world's undiscovered natural gas (U.S. Geological Survey, 2008), making it too lucrative a frontier for China to ignore, especially with the current plan to increase the use of LNG to $10 \%$ by 2020 and $15 \%$ by 2030 (Xinhua, 2019).

Not only domestic but also global environmental issues affect social stability in China. The Chinese government must equally respond to these challenges in order to prevent instances of civil disorder. Out of such global challenges, climate change can be seen to pose the most severe risks. In the future, climate change is expected to cause floods, drought and extreme weather events in China, all of which can potentially affect not only the everyday life of Chinese citizens but also the country's agriculture and food production, security of supply and military strategies. There 


\section{China and the Arctic environment}

seems to be no apparent dispute about these impacts, let alone climate change itself, in China. On the contrary, the Chinese government has openly acknowledged that global warming threatens the country's national security. Most tellingly, China's Arctic strategy and most major policy speeches all emphasize the severe consequences of climate change on China (State Council Information Office of the People's Republic of China, 2018; e.g. Zhang, 2015).

In addition to finding a balance between growth and its costs, another factor that is crucial to the legitimacy of the Chinese government is its prowess on the international stage. Due to the growing environmental awareness of the Chinese people, taking responsibility for global climate change in such contexts as the Arctic high-level meetings is likely to promote a better image of the Chinese government and the ruling party among the domestic audience. Indeed, as China rises to the status of a global power and the Chinese society becomes increasingly open and integrated with the rest of the world, Chinese people are likely to evaluate their government's worth in terms of both domestic and international achievements, a fact that is recognized by the party-state in its portrayal of China's participation in Arctic science activities, for example at the National Museum of China in Beijing (see Kopra \& Kauppila, 2018). This creates a strong incentive to replenish China's international image in environmental issues and gain a stronger foothold in international climate politics.

\subsection{From Rio to Paris: China's changing role in international climate politics}

The United Nations Framework Convention on Climate Change (UNFCCC) was adopted in Rio de Janeiro in 1992 and entered into force in 1994. As of 2019, it has been ratified by 197 countries is often referred to as 'the Parties to the Convention' (UNFCCC, 2019). The Convention marks an important step for international climate politics because, for the first time, countries agreed to stabilize greenhouse gases (GHG) at a non-hazardous level in order to prevent climate change. China ratified the Convention in January 1993. However, for a long time, China refused to shoulder any responsibility in the UN negotiations for climate change mitigation and highlighted the historic responsibility of developed countries to reduce emissions as well as to aid developing countries to handle the adverse effects of climate change.

The legally-binding Kyoto Protocol was negotiated in 1997 and entered into force as late as 2005. The burden-sharing of the Kyoto Protocol for 2008-2012 set quantitative emission 


\section{China and the Arctic environment}

reductions only for developed countries, including the members of the Organization for Economic Co-operation and Development (OECD) in 1992 and the Economies in Transition including the Russian Federation, the Baltic States, and a number of Central and Eastern European States (UNFCCC, 2019). The rest of the Parties were not required to reduce their emissions, as they were seen as developing countries. This group included emerging nations such as China, South Africa, Brazil and India. The Protocol covered only some 30 percent of global emissions because, amongst other factors, the United States (US) never ratified it, and the growing emissions of emerging nations were excluded from the quotas (Durand, 2012; Syri et al., 2013). In reality, the number is ambiguous since, for example, in 2011 Japan and Russia announced that they would withdraw from the protocol (Korhola, 2014). In 2012, only 19 out of 41 countries were expected to achieve the given reductions, and on the contrary, emissions actually continued to grow in many of the OECD countries (Hurrell, 2012; Napoli, 2012). Developing countries' position of not having binding emission obligations in the Protocol is suggested to be a merit of China for its role as the leading negotiator in the developing country group G-77 (Chen, 2012). G-77 represents one major group in climate politics and is an important negotiation coalition for China to be included in with its 133 members covering $2 / 3$ of the world's nations. However, the group of developing countries has become more diverse, the interests of the group conflict more, and the common identity has moderately deteriorated, thereby putting into question the practicality of the group in climate negotiations (Blaxekjær \& Nielsen, 2015).

China's first National Program on Climate Change was published in 2007, clearing awareness of climate change and promising to agree on voluntary targets for energy consumption. At that stage, China was unable to commit to binding emission targets because of its coal-dominated energy structure and low per capita income levels (Chen, 2012). In COP13 (conference of parties) in Bali in 2007, climate action was requested from all Parties for the first time - mitigation commitments from developed countries and mitigation actions from developing countries (Brunnée \& Streck, 2013). The outcome of COP13 also urged the Parties to come to an agreement by 2009, which led to the high expectations for COP15 in 2009 in Copenhagen. In COP15, Parties disagreed whether to format the agreement to extend the mandate of the Kyoto Protocol or negotiate a new agreement (Christoff, 2010). In the end, the conference came out only with a weak Copenhagen Accord, from which many blame the emerging nations' negative attitude, especially that of China and India (Hallding et al., 2011; 


\section{China and the Arctic environment}

Hurrell, 2012; Brunnée \& Streck, 2013). Despite the weak outcome, the legacy of Copenhagen can be seen in the strengthening position of the emerging nations within climate politics (Hallding et al., 2011). In 2009, the emerging nations Brazil, South Africa, India and China founded an annual negotiation coalition, called The BASIC Countries, as a subgroup for the developing country bloc G-77 with motivation to strengthen the position of developing countries (ibid.)

Until the 2011 COP17 in Durban, China had determinedly refused to agree to any binding climate obligations, preferring voluntary national objectives. However, in 2011 in Durban, the Parties agreed to commit to a new legally-binding climate agreement by 2015 to be entered into force in 2020 (Roberts, 2016). At this point, all eyes turned to Paris COP21 with expectations as great they were before Copenhagen's meeting in 2009. After Durban, China took a more constructive role in international climate negotiations. The remarkable difference in China's role in 2009 in Copenhagen in comparison to Paris in 2015 results from the prioritization shift in economic development in China's 12th Five-Year Plan from energy-intensive growth to innovation and low-carbon technologies (Hilton \& Kerr, 2017). This change enabled China to reformulate its international climate priorities before Paris. For instance, in 2013, the government stated that "Since 2012, the Chinese government has taken positive action in enhancing its capability across major sectors to adapt to climate change and respond to extreme weather and climate-related events" (National Development and Reform Commission, 2013: 27).

In particular, China began to cooperate with the United States on climate change - a crucial development that can be seen as a critical driver to the adoption of a new international climate agreement at the COP21 held in Paris in 2015. The Sino-American climate cooperation flourished in particular during the Obama administration, and between 2013 and 2016, China and the United States issued several joint statements in which the two nations agreed on their shared urgency to solve climate change (e.g. National Development and Reform Commission, 2014; 2015; 2016). In 2014, China and the US made an emission-cutting agreement which has been acknowledged as significant also on the global level. In the agreement, China pledged to halt carbon emissions growth around 2030. Also, it pledged 3.1 billion USD to developing countries to address climate change (National Development and Reform Commission, 2015). The deal gained widespread international attention prior to COP21, and the text directly encouraged other Parties to be inspired by the Sino-American effort and to submit their own contributions. The 


\section{China and the Arctic environment}

image of an uncooperative country, as China was accused of being in the negotiations in 2009, was at least partly gone in Paris in 2015.

\subsection{China and international climate politics in the Paris era}

In COP21, Parties delivered the Paris Agreement on the 12th December 2015 with the main targets of halting the global average temperature increase to below $2^{\circ} \mathrm{C}$ whilst also attempting to limit it to $1.5^{\circ} \mathrm{C}$ and reaching net zero emissions after 2050 (Ge et al., 2019). The Paris Agreement was opened for ratifications on 22nd April 2016 and entered into force on 4th November 2016 after reaching the threshold of being ratified by 55 Parties accounting for a minimum of $55 \%$ of global emissions on 5th October 2016 (UNFCCC, 2019). Paris requires 55\% of all global emissions, while in comparison, the Kyoto Protocol covered only 55\% of the emissions of industrialized countries. In Paris, China agreed for the first time to an absolute cap on emissions, dependent on international measurements, reporting and verification (MRV) (Hilton \& Kerr, 2017).

The Paris Agreement is based on states' voluntary, nationally-determined contributions that were first called Intended Nationally Determined Contributions (INDC) as nations were submitting their first ones prior to the finalization of the Agreement. INDCs changed to Nationally Determined Contributions (NDCs) without the prefix "intended" when a Party ratified the Paris Agreement. NDCs are drafted at the national level, considering the domestic circumstances and capabilities (Dalby, 2016). At the same time, the Paris Agreement contains several procedural obligations, including that each NDC should reflect the highest possible ambition and progress beyond the existing pledge. A further important element of the Paris Agreement is its international reporting and transparency framework.

Nationally-determined contributions support the climate negotiation process to shift further towards a bottom-up approach and currently represent the public prime channel between the international and national climate politics. Thus, the long-term success of the agreement depends on the NDCs' ability and ambition to respond to the targets of the Paris Agreement.

NDCs were an important source of encouragement for China's positive attitude towards the Paris Agreement since they represent an important bottom-up and voluntary option to traditional reduction quotas (Hilton \& Kerr, 2017). China submitted its comprehensive 40-page long NDC to the UNFCCC in June 2015, which promises by 2030: 


\section{China and the Arctic environment}

a) to achieve the peak of carbon dioxide emissions around 2030 and to conduct their best efforts to peak early;

b) to lower carbon dioxide emissions per unit of GDP by $60 \%$ to $65 \%$ from the 2005 level;

c) to increase the share of non-fossil fuels in primary energy consumption to around $20 \%$; and

d) to increase the forest stock volume by around 4.5 billion cubic meters on the 2005 level (China's National Development and Reform Commission, 2015).

To achieve these 2020 and 2030 targets, the NDC document of China introduces a number of actions, of which the majority have already been implemented (den Elzen et al., 2016). The document highlights the significant impact that developed countries have had on the emissions and defines China as a responsible developing country. The contribution also explains China's will to increase the South-South climate cooperation and China's wish to assist other developing countries facing climate change, including small island nations, the least developed countries and African countries. The document describes China as motivated to act on climate change because of the domestic need for sustainable development and the will to ensure economic, energy, ecological and food security and people's health in addition to China's willingness for global cooperation. However, the NDC document does not mention China or climate change in the context of the Arctic region. The document is in agreement with the ideas of the 13th Five-Year Plan as China is said to aim for a "moderately prosperous society in an all-around way by 2020 and to create prosperous, strong, democratic, culturally developed and harmonious modern socialist country by the middle of this century" (China's NDC, 2015: 4).

The Paris Agreement is credited for its symbolic value of Parties coming into an agreement of legally-binding terms but criticized for the wide gap between the ambition of the NDCs and the actual targets of the agreement. For example, China's NDC is 'little more than business as usual' (Harris, 2017: 102) and "highly insufficient" in order to reach the goal to limit the global temperature rise to $2^{\circ} \mathrm{C}$ unless other states do not implement much more ambitious emissions reduction measures (Climate Action Tracker, 2018).

In 2016, the Sino-American climate cooperation was influenced by the US political situation as the Republican Party in the US has, at least until this far, not supported active 


\section{China and the Arctic environment}

international climate policy (Kemp, 2016). A few days after the Paris Agreement had entered into force, climate sceptic Republican Donald J. Trump was elected US president. During his election campaign, several times Trump called climate change a 'Chinese hoax' as well as announced to nullify the climate policies made by the Obama administration. Therefore, Trump's election instantly elevated China into a new position as a global climate leader - whether or not it wanted it or was ready for that in practice (Kopra, 2019). The Chinese government seemed to respond to international expectations of its leadership role positively, and many officials convinced the international community that China would not change its approach to international climate policy despite Trump's negative approach. In June 2017, Trump indeed decided to withdraw the US from the Paris Agreement, which caused harsh criticism around the world and ended the Sino-American cooperation on climate change. As a leadership vacuum in international climate negotiations emerged, the international society began to expect China to step in. Notably, the Chinese government did not stand to oppose these expectations, but pledged to increase cooperation with the European Union instead. Remarkably, president Xi Jinping declared in his speech to the 19th National Congress of the Communist Party of China that China had taken a "driving seat" in international climate negotiations and hence had "become an important participant, contributor, and torchbearer in the global endeavor for ecological civilization" (Xi, 2017: 4).

In COP24 in Katowice in 2018, Parties were urged to agree on implementation, and the conference finally delivered a rulebook for the Paris Agreement. In the Paris Agreement, Parties committed to an ambition mechanism regarding the NDC documents: approximately every five years, Parties must submit a new, more ambitious, nationally-determined contribution to UNFCCC. Critics to the 2018 Paris rulebook were quick to point out that the commitment for increased ambition is not defined clearly enough in the key chapter of the rulebook. Hence, the expectations vary for the second round of NDCs. The Marshall Islands were the first country to submit their second NDC in November 2018 but the other Parties, including China, are expected to submit theirs during 2019 and 2020 (UNFCCC INDC Submission Portal, 2019). The ambition mechanism was meant to make the Paris Agreement responsive to the message of the 2018 Intergovernmental Panel on Climate Change (IPCC) special report and to enable Parties to scale up their commitments to reach the $1.5^{\circ} \mathrm{C}$ target. However, at present, it remains unclear whether China is willing to enhance its NDC under the Paris Agreement in an ambitious manner or whether 


\section{China and the Arctic environment}

it will more determinately emphasize the historic responsibility of developed countries - as it and other BASIC (Brazil, South Africa, India and China) countries did in the UN climate negotiations in Bonn in 2017. China's historical emissions will soon override the other Parties' but China can still argue for its lower per capita emissions which will still be, thanks to the great population, a real argument in the near future (Woon, 2018). With the business-as-usual model, also the per capita emissions of China will reach the average of the developed countries by 2030 (IEA, 2011).

The increased cooperation between the EU and China especially from 2018 onwards could support China to submit a more ambitious pledge. In particular, the agreement that China and the EU made in July 2018 to intensify their cooperation on climate change and clean energy is a positive sign, and there are many opportunities for collaboration in the fields of emissions trading systems, energy efficiency, clean energy and technology, low-emission transportation, and low-carbon cities, etc. In April 2019, the two nations published the EU-China Summit Joint Statement (2019) in which they express the will to a deeper cooperation in addressing global environmental challenges such as pollution and marine litter. The statement was viewed "promising" by Europe's largest coalition of non-governmental organizations working on climate and energy issues (CAN Europe, 2019).

\subsection{China's Arctic strategy and climate change}

In January 2018, China's State Council Information Office published its long-awaited Arctic white paper. According to the paper, the state's goals in the region include "to understand, protect, develop and participate in the governance of the Arctic, so as to safeguard the common interests of all countries and the international community in the Arctic, and promote sustainable development of the Arctic". "While pursuing its own interests", the white paper explains, "China will pay due regard to the interests of other countries and the broader international community, bear in mind the importance of the protection and development of the Arctic, and of keeping in proper balance its current and long-term interests, so as to promote the sustainable development of the Arctic". The white paper identifies "sustainability" as "the fundamental goal" of China's Arctic engagement, which, in turn, "means promoting the sustainable development of the Arctic by ensuring the sustainability of environmental protection, resource utilization and human activities in the area". Furthermore, it "means realizing harmonious coexistence between man 


\section{China and the Arctic environment}

and nature, better coordination between ecological protection, economic growth and social progress, better balance between utilization, management and protection, and intergenerational equity" (State Council Information Office of the People's Republic of China, 2018). Notably, the white paper does not mention the concept of ecological civilization at all.

Defining China as a 'near-Arctic state', China's Arctic white paper emphasizes that the "natural conditions of the Arctic and their changes have a direct impact on China's climate system and ecological environment, and, in turn, on its economic interests in agriculture, forestry, fishery, the marine industry and other sectors" (State Council Information Office of the People's Republic of China, 2018). Scientific findings do indeed show that Arctic climate change causes risks to human security and ecosystems in China. For example, many of China's coastal mega-cities, such as Shanghai, Tianjin and Hong Kong, are expected to suffer from flooding due to rising sea levels caused by the melting of sea ice in the Arctic. Moreover, Arctic climate change is also expected to increase haze pollution in eastern China (Wang, Chen \& Liu, 2015) as well as alter many global natural processes, causing changes likely to hamper China's agricultural production. As discussed above, air pollution and food security are critical factors of the legitimacy of the Chinese Communist Party. Therefore, it is unsurprising that scientific research on climate change is one of the key interests of China's Arctic policies, and the Chinese government wants to learn more about the linkages between Arctic climate change, natural cycles, domestic interests, and social stability in China (for more information, see Chapter 4).

Although China's Arctic white paper notes that "China's emission reduction measures have a positive impact on the climatic and ecological environment of the Arctic", it does not introduce additional measures to reduce greenhouse gas emissions in China. Thus, China's Arctic strategy pays more attention to the link between Arctic climate change and the adverse effects of climate change in China than to the ways in which the world's largest carbon emitter could mitigate Arctic climate change. A key reason for this may be that China uses "climate change as a key justification for its Arctic engagement" (Kopra, 2020), and it argues that due to Arctic climate change's adverse effects on the Chinese society, the Chinese government has special interests in the region and it should be accepted as a legitimate participant in the regional governance. However, China could also legitimate its growing regional role by announcing additional, ambitious measures to cut greenhouse gas emissions, a move that China's Arctic strategy fails to take. In broader terms, such tightening of domestic climate policy measures 


\section{China and the Arctic environment}

would prove to the world that China is ready to play a leadership role in international climate policy (Kopra, 2019).

\subsection{China and global cooperation on SLCPs}

Global cooperation efforts have expanded recently to cover emissions of SLCPs, the reduction of which helps mitigate short-term climate change and, in some cases, air pollution. ${ }^{5}$ As explained above, SLCPs refer to GHGs such as methane, some HFCs and tropospheric ozone as well as black carbon, which is an aerosol. What unites them under one label - apart from their climate impact is their relatively short lifetime in the atmosphere compared to $\mathrm{CO} 2$. This implies that rapid reduction in SCLPs will lead to relatively quick gains in terms of climate change mitigation. That said, reducing SLCPs is viewed as only complementary to $\mathrm{CO} 2$ reductions, which are essential for addressing long-term global climate change (Intergovernmental Panel on Climate Change, 2014: 20). In addition, methane, tropospheric ozone and black carbon contribute to air pollution, which implies that there are significant co-benefits of their reductions for public health and the environment.

Many international regimes and institutions are relevant for reducing SLCPs and hence the related legal and governance regime is complex and fragmented. Methane and HFC emissions have traditionally been discussed under the UNFCCC. The latter have also recently been designated to be phased out under the Kigali amendment to the Montreal Protocol on Substances that Deplete the Ozone Layer.

In addition to these, in the last decade global initiatives have emerged to draw attention specifically to SLCPs and the co-benefits of their reductions. The main initiative is the Climate and Clean Air Coalition (CCAC), a voluntary government-led partnership that was launched in 2011 with the goal to raise awareness and improve scientific understanding of SLCPs, build capacities, strengthen national and regional actions, and promote best practices. The Coalition has been successful in generating support from 64 states and 73 intergovernmental and non-

5 This section draws on Yamineva \& Liu 2019; and Yamineva \& Kulovesi 2018. 


\section{China and the Arctic environment}

governmental organizations thus far. China is not a member of the CCAC but participates in its meetings as an observer state.

The Arctic Council has also been proactive in addressing SLCPs, specifically black carbon and methane emissions. It has done so through scientific assessments and the adoption of the Framework for Action on Enhanced Black Carbon and Methane Emission Reductions (Arctic Council, 2015a). Under the Framework, the Arctic States committed themselves to taking national mitigation actions and to a collective goal to limit black carbon emissions to between $25 \%$ and 33\% below 2013 levels by 2025 (Arctic Council, 2017). The Framework also aims to raise awareness of SLCPs among observer states whose emissions impact the Arctic and to welcome their participation in the implementation of the Framework, for instance in the development and improvement of emissions inventories. Indeed, seven observer states, including France, Poland, Japan, Korea, and India, along with the EU have voluntarily submitted their national reports on black carbon and methane emissions reductions (Arctic Council, 2015b). As of May 2019, China has not submitted its national report.

China's passive stance when it comes to participating in global cooperation on SLCPs is partly explained by the immaturity of its domestic discussion and policy approach to the subject. There has been limited attention on the part of policy-makers to methane and black carbon emissions, although there are signs of that changing. China's domestic climate policy has primarily focused on $\mathrm{CO} 2$, and this approach is reflected in its NDC to the UNFCCC, which includes only $\mathrm{CO} 2$ targets. In principle, as $\mathrm{CO} 2$, methane and black carbon are often co-emitted by the same sources, measures to reduce $\mathrm{CO} 2$ emissions will lead to reductions in SLCPs; however, the degree of such reductions is unclear. China's 13th FYP highlights the importance of tackling non-CO2 GHGs but specific policy measures are yet to be developed. On black carbon, the main challenge is insufficient data on emissions and limited understanding of their sources, impacts and mitigation pathways. There are no policies targeting black carbon emissions per se; however, black carbon is a component of PM2.5, which is covered by quantified air quality targets. Overall, synergies between climate and air quality goals have been receiving more and more recognition in recent

policies, for instance in the new Three-year Action Plan for Winning the Blue Sky War (20182020); however, related actions are still short on detail. 


\section{China and the Arctic environment}

\subsection{China's domestic climate, air quality and energy policies}

China is the largest energy consumer and largest emitter of $\mathrm{CO} 2$ emissions in the world; Between 1978-2014, China's total energy production increased annually by $4.83 \%$ and its total energy consumption by $5.58 \%$ (Zhang et al., 2017). Since the late 2000s, China has formulated various domestic policies to reduce the growth of greenhouse gas emissions. Its climate mitigation policies have mostly focused on $\mathrm{CO} 2$ emissions, as explained above. However, China has not indicated how much its emissions will grow before they peak. Between 2014 and 2016, it seemed that the peak had already been reached. In 2017, however, China's carbon dioxide emissions grew again to $9.1 \mathrm{Gt}$, which is a $1 \%$ increase from the 2014 emission level (IEA, 2018). Despite this negative trend towards peaking, in 2017 China's economy grew by 7\%, which could have caused emissions to increase more, but thanks to the deployment of renewables and accelerating the switch from coal to gas, overall emissions grew only by $1.7 \%$ (ibid.). Though coal demand seemed to peak in China in 2013, the growing energy demand has increased energy-related emissions by raising the demand for oil and gas (ibid.). The scenarios of the possible peak in Chinese emissions vary considerably depending on GDP growth assumptions and the development of policy implementation, amongst other factors (den Elzen et al., 2016). All these scenarios agree that reaching the peak before 2030 would require China to implement new climate policies (ibid.)

Like elsewhere, energy policy plays an especially important role in China's climate policy. To decrease reliance on coal and other (imported) fossil fuels, China's 13th Five-Year Plan orders an increase in the proportion of non-fossil fuel energy to 15 percent of total energy consumption and a decrease in the consumption of coal to below 55 percent. In efforts to promote the production of non-fossil fuel energy, hydropower and nuclear energy are important. China is the biggest source of hydropower in the world, and the installed capacity of hydropower exceeded 100,000 megawatts in 2004, 200,000 megawatts in 2010 and 300,000 megawatts in 2015 (Li et al., 2018). Still, China's huge hydropower projects such as the Three Gorges Dam (Sanxia Daba 三峡大坝) have caused severe social and environmental damage on a local scale. In April 2019, there were 45 nuclear plants in operation, about 15 under construction, plus more about to start construction on mainland China, meaning that the number of nuclear power plants has increased more than tenfold since 2000 (World Nuclear Association, 2019). 


\section{China and the Arctic environment}

Furthermore, China has invested heavily in renewable energy and is unquestionably the leader of renewable growth - Chinese renewables now account for $16.7 \%$ of the global total (IEA, 2017; Zhang et al., 2017). It is the world leader in solar energy by manufacturing about 60 percent of global solar cell capacity and by using about half of global solar power per year. In 2017 alone, China installed at least 50 gigawatts of solar power capacity, which means that it already exceeded the 13th Five-Year Plan's target of 105 gigawatts (Buckley, Nicholas \& Brown, 2018). Solar power will affect China's energy mixture dramatically in the future (Zhang et al., 2017).

Moreover, China has abundant wind energy resources and it is able to develop wind power on a large scale (Sahu, 2018). In 2016, China represented 35 percent of global cumulative wind power installations. The objective of the 13th Five-Year Plan for wind power is at least 210 gigawatts, and China is expected to achieve the target in 2019 (IEA, 2017). China's Arctic white paper defines the region as a source of "clean" energy:

The Arctic region boasts an abundance of geothermal, wind, and other clean energy resources. China will work with the Arctic States to strengthen clean energy cooperation, increase exchanges in respect of technology, personnel and experience in this field, explore the supply of clean energy and energy substitution, and pursue low-carbon development (State Council of the People's Republic of China, 2018).

The government has made serious efforts to decrease energy demand by promoting energy conservation and energy efficiency. The growth of renewables is still challenged by the lack of adequate technology and innovation, as for instance a remarkable share of the renewable generation capacity is currently wasted because of insufficient electricity grids (Zhang et al., 2017). The government has closed ineffective power plants and small or outdated industrial factories, promoted the development of modern, energy-saving technology and products and has also established national standards to improve automotive fuel economy, for instance. The Chinese government also employs market approaches to reducing emissions although these are viewed as mostly complementary to traditional command-and-control policies (Duan, 2015). A national carbon market was launched in 2017 with the initial focus on the power sector (Pike \& 


\section{China and the Arctic environment}

Zhe, 2017). The market was designed to be the world's largest emissions trading system, accounting for about $30 \%$ of national emissions with a coverage of 1700 power companies and three billion tonnes in total greenhouse gas emissions (ICAP, 2019).

Despite the growth of renewables and the launching of the carbon market, coal represents an important role in China's economic development and currently accounts for $70 \%$ of the primary supply (Zhang et al., 2017). Hence, the total energy mixture requires a greater change in order to be able to reach peak emissions by 2030 .

The number of cars is expected to more than triple by the end of the next decade in China, which could cause severe air pollution locally and inhibit the states from reaching peak emissions by 2030 (Zheng et al., 2015). In order to boost the development of electric vehicles, the government has launched many plans and policies, the most influential being the announcement to ban the production and sale of fossil fuel cars in the near future. In 2018, China also issued the China VI Emission Standard (Guoliu Paifang Biaozhun 国六排放标准) that orders all new diesel heavy-duty vehicles introduced to the market after July 2021 to have diesel particulate filters. If efficiently implemented, this means that all new heavy duty vehicles in China will be soot-free after 2021 (Cui \& Minjares, 2018).

Furthermore, the development of green technologies plays an important role in China's efforts towards the 'greenization' of its society as well as developing the country as a 'knowledge power'. China's participation in Arctic LNG projects supports these goals by increasing (technical) knowhow, and the government is making efforts to replace coal and oil with natural gas, a less environmentally-harmful fossil fuel. A good example of linkages between Chinese and Arctic partners in the area of renewable energy is a large-scale joint geothermal project between Sinopec (Zhongguo Shihua 中国石化) and the Arctic Green Energy Corporation, with the latter partner being focused on utilising Icelandic geothermal energy expertise internationally (Arctic Green Energy Corporation, n.d.).

Due to public discontent caused by 'Airpocalypses' (severe haze and smog episodes in many Chinese megacities), the Chinese government has taken the issue of air pollution seriously. For example, in 2014 it declared a 'War Against Pollution', a major campaign targeted at altering energy production and consumption (State Council of the People's Republic of China, 2014), whereas in 2016, the government issued a "Healthy China 2030 Plan", which underlined the efforts to tackle the health impacts of the country's environmental challenges (Central 


\section{China and the Arctic environment}

Committee of the People's Republic of China, 2016). For instance, the Air Pollution Action Plan (2013-2017) forced key regions to significantly decrease PM2.5 levels, resulting in dramatic improvements of air quality in Beijing (Zheng et al., 2018). Moreover, the 13th Five-Year Plan (2016-2020) (Shisanwu Guihua “十三五”规划) pledges to “ensure that the concentration of fine particulate matter is reduced by at least $25 \%$ " and sets key indicators for air quality: the percentage of days experiencing "good" or "excellent" air quality in cities at and above the prefectural level, with the target being 80 percent. The cities that fail to meet the target percentage should reduce PM2.5 intensity by 18 percent. These targets were reiterated by the Three-Year Action Plan (Sannian Xingdong Jihua 三年行动计划) for Winning the Blue Sky War (2018-2020) (Daying Lantian Baoweizhan 打赢蓝天保卫战), published in July 2018.

China's efforts to move away from coal-based energy production domestically stand somewhat in contrast to its investments abroad. A recent report by the Institute for Energy Economics and Financial Analysis highlighted that a significant percentage of Chinese offshore investments - including primary financing provided by China's state-controlled financial institutions - go into coal projects in South-East Asia, the Indian Ocean basin and in Africa in general. The report states that "Chinese finance continues to play a significant role in global coal development, supporting over one-quarter of all coal plants currently under development outside China" (Shearer, Brown \& Buckley, 2019). This comes at a time when many other financial institutions, including the World Bank, multilateral development banks, or OECD countries' financial institutions, among others, are pulling out of such investments due to both climate and environmental goals as well as poor long-term economic assessments of coal energy projects. Chinese investments in coal projects lock in a significant amount of carbon emissions for 40 to 50 years. Simultaneously, Chinese companies are being provided with contracts related to construction and management of coal power plants, which partly explains the continued willingness of Chinese financial institutions to engage in such projects.

Other Chinese foreign investments can also be considered from the viewpoint of their long-term climate impacts, in particular in reference to resource extraction projects. The recent Global Resources Outlook (International Resource Panel, 2019) highlighted that around 17\% of global emissions are related to the extraction and refining of non-energy resources before these are used in manufacturing. A further $17 \%$ of emissions are connected to the extraction and 


\section{China and the Arctic environment}

refining of fossil fuels, even before these are burned for energy. Therefore, Chinese mining projects abroad - as with all other foreign resource extraction financing - should be a part of the evaluation of the climate impacts of overseas investments.

\subsection{Conclusions}

China is the world's biggest CO2 emitter and a significant contributor of SLCPs and other pollutants that cause environmental harm in the Arctic and beyond. In addition, the ecological footprint of China's BRI continues to be large, especially due to investments in the coal industry. Hence, China plays a crucial role in climate and environmental protection in the High North. Given the state's 'highly insufficient' ambition to limit the global temperature rise to $2 \mathrm{C}$ or $1.5 \mathrm{C}$ (Climate Action Tracker, 2018), raising the level of ambition of China's climate mitigation pledged in the second NDC would clearly be necessary for a resilient future of the region (and the whole planet). However, China is not likely to commit itself to a very ambitious emissions reductions target in the future; such a commitment would cause a high risk of 'losing face' in the case of failing to reach the target. Yet climate change mitigation and adaptation are in China's domestic interest, as is engagement in global cooperation, and it will continue to play an active role in the implementation of the Paris Agreement. This is also important for preventing environment-related protests at home and, thus, maintaining social stability and the communist party's ruling position in the country.

Although it is unlikely that China can commit to a significantly more ambitious mitigation target in the near future, there are several openings that can be explored to strengthen the involvement of China in global cooperation on climate change. For instance, though China has made great progress with renewable energy production, the share of renewables in China's energy mix still remains below the world average because of the high energy demand. The increase in the share of renewable energy offers China a good option to enhance the ambition level of its climate policy in the near future. Another opportunity for China arises in emphasizing interconnections between air quality, public health and climate policies in such cases as through the focus on SLCPs. Opportunities should be explored to engage China more closely in the related work under the Arctic Council and the CCAC. Given that adequate scientific knowledge and emission inventories are a prerequisite to stronger actions, scientific cooperation also needs to be strengthened through 


\section{China and the Arctic environment}

both scientific organizations and science-policy bodies such as the IPCC. Moreover, the "greenification" of the BRI projects would be necessary in order to reach the goals of the Paris agreement. Chinese financing institutions should assess and be transparent about the climate and environmental footprint of the investments they support, in particular those related to resource extraction, fossil fuels and coal power.

Beyond climate change, it would be important to assess the Arctic footprint of China's domestic emissions of pollutants that are prone to long-range transport into the Arctic environment, including persistent organic pollutants and mercury. The understanding of such impacts should be taken into account in future policymaking aimed at emissions reductions. In this way, China could show that it carries out domestic environmental policies in a way that contributes to the sustainability principles stated in the country's Arctic white paper.

\section{Literature}

ACIA. (Arctic Climate Impact Assessment). (2004). Impacts of a warming Arctic: Arctic climate impact assessment. Retrieved August 14, 2019, from http://amap.no/acia/.

Albert, E., \& Xu, B. (2016). China's environmental crisis. Backgrounder. Council on Foreign Relations. Retrieved August 14, 2019, from https://www.cfr.org/backgrounder/chinasenvironmental-crisis.

Allen, S., Allen, D., Phoenix, V. R., Le Roux, G., Durántez Jiménez, P., Simonneau, A., ... Galop, D. (2019). Atmospheric transport and deposition of microplastics in a remote mountain catchment. Nature Geoscience, 12, 339-344.

AMAP. (Arctic Monitoring and Assessment Programme). (2009a). AMAP Assessment 2009: Human health in the Arctic.

AMAP. (Arctic Monitoring and Assessment Programme). (2009b). Arctic pollution 2009: Persistent organic pollutants, radioactivity, human health. Oslo, Norway. 
AMAP. (Arctic Monitoring and Assessment Programme). (2015). Summary for policy-makers: Arctic climate issues 2015. Oslo, Norway.

AMAP. (Arctic Monitoring and Assessment Programme). (2017). Snow, water, ice and permafrost in the Arctic (SWIPA) 2017. Retrieved August 14, 2019, from https://www.amap.no/documents/doc/Snow-Water-Ice-and-Permafrost-in-the-Arctic-SWIPA$2017 / 1610$.

Arctic Council. (2015a). Annex 4. Iqaluit 2015 SAO Report to Ministers. Enhanced black carbon and methane emission reductions: An arctic council framework for action. Retrieved August 14, 2019, from https://oaarchive.arctic-council.org/handle/11374/610.

Arctic Council. (2015b). Arctic Council observer states 2015 national reports on enhanced black carbon and methane emissions reductions. Retrieved October 20, 2018, from https://oaarchive.arctic-council.org/handle/11374/1169.

Arctic Council. (2017, May 11). Fairbanks Declaration. Retrieved August 14, 2019, from https://oaarchive.arctic-council.org/handle/11374/1910

Arctic Green Energy Corporation. (n.d.). Arctic green energy corporation. Retrieved November 9, 2018, from http://arcticgreencorp.com

Babones, S. (2017). Red alert for China's pollution protesters. AlJazeera. Retrieved August 14, 2019, from https://www.aljazeera.com/indepth/opinion/2017/02/red-alert-china-pollutionprotesters-170217111717375.html.

Blaxekjær L., \& Nielsen, T. (2015). Mapping the narrative positions of new political groups under the UNFCCC. Climate Policy, 15(6), 751-766. 
Bond, T. C., Doherty, S. J., Fahey, D. W., Forster, P.M., Berntsen, T., DeAngelo, B. J., ... Zender, C. S. (2013, June 16). Bounding the role of black carbon in the climate system: A scientific assessment. Journal of Geophysical Research: Atmospheres, 118(11), 5380-5552.

Brunnée, J., \& Streck, C. (2013). The UNFCCC as a negotiation forum: Towards common but more differentiated responsibilities. Climate Policy, 13(5), 589-607.

Buckley, T., Nicholas, S., \& Brown, M. (2018). China 2017 review. World's second-biggest economy continues to drive global trends in energy investment. Cleveland, $\mathrm{OH}$ : Institute for Energy Economics and Financial Analysis.

CAN Europe. (2019, May 9). EU and China point to the UN Secretary General's climate summit as an important milestone. Climate Action Network Europe. Retrieved August 14, 2019, from http://www.caneurope.org/publications/press-releases/1756-eu-and-china-point-to-the-unsecretary-general-s-climate-summit-as-an-important-milestone

Cavalieri, S., McGlynn, E., Stoessel, S., Stuke, F., Bruckner, M., Polzin, C., ... Nilsson, A. E. (2010). The EU Arctic footprint and policy assessment. Report summary. Retrieved June 20, 2018, from https://arctic-footprint.eu/sites/default/files/AFPA_Summary_Report.pdf

Central Committee of the People’s Republic of China. (2016). 健康中国2030”规划纲要 [Healthy China Plan 2030]. Retrieved August 14, 2019, from http://www.gov.cn/zhengce/201610/25/content_5124174.htm.

Chen, G. (2012). China's climate policy. China Policy Series (pp. 144). London, England: Routledge.

China's National Development and Reform Commission. (2015, June 30). Enhanced action on climate change: China's intended nationally determined contributions. Retrieved June 20, 2018, from 
http://www4.unfccc.int/ndcregistry/PublishedDocuments/China\%20First/China\%27s\%20First\% 20NDC\%20Submission.pdf

China's NDC. (2015). Enhanced actions on climate change: China's intended nationally determined contributions. Unofficial translation. Retrieved August 14, 2019, from <https://www4.unfccc.int/sites/ndcstaging/PublishedDocuments/China\%20First/China's\%20First $\% 20$ NDC\%20Submission.pdf>

Christoff, P. (2010). Cold climate in Copenhagen: China and the United States at COP15. Environmental Politics, 19(4), 637-656.

Climate Action Tracker. (2018). China. Retrieved August 14, 2019 from https://climateactiontracker.org/countries/china/

Cui, H., \& Minjares, R. (2018). China VI: A milestone for the world's transition to soot-free vehicles. International Council on Clean Transportation. Retrieved November 20, 2018, from https://www.theicct.org/blog/staff/china-vi-milestone-world\%E2\%80\%99s-transition-soot-freevehicles

Dalby, S. (2016). Interpreting climate geopolitics: Knowledge, power, and security. Geopolitics, 21(1), 236-241.

Duan, M. (2015). From carbon emissions trading pilots to national system: The road map for China. Carbon \& Climate Law Review, 9(3), 231-242.

Durand, A. (2012). Common responsibility: The failure of Kyoto. Harvard International Review, 34(1), 8-9.

EDGAR. (2017). Fossil CO2 \& GHG emissions of all world countries, 2017. Retrieved August 14, 2019, from https://edgar.jrc.ec.europa.eu/overview.php?v=CO2andGHG1970$2016 \& d s t=C O 2 p c$. 
den Elzen, M., Feketeb, H., Höhneb, N., Admiraala, A., Forselld, N., Hof, A. F., ... van Soes, H. (2016). Greenhouse gas emissions from current and enhanced policies of China until 2030: Can emissions peak before 2030? Energy Policy, 89, 224-236.

EU-China Summit Joint Statement. (2019). Outcome statement. Retrieved August 14, 2019, from <https://www.consilium.europa.eu/media/39020/euchina-joint-statement-9april2019.pdf>

Ge, M., Lebling, K., Levin, K., \& J. Friedrich (2019). Tracking Progress of the 2020 Climate Turning Point. World Resources Institute. Working Paper. Retrieved August 14, 2019, from <https://wriorg.s3.amazonaws.com/s3fs-public/2020-turning-pointprogress_2.pdf?_ga=2.77395413.191076062.1560251648-569271310.1556197040>

Gu, Y., Wong, T. W., Law, C. K., Dong, G. H., Ho, K. F., Yang, Y., \& Yim, S. H. L. (2018). Impacts of sectoral emissions in China and the implications: Air quality, public health, crop production, and economic costs. Environmental Research Letters, 13(8).

Hallding, K., Olsson, M., Atteridge, A., Vihma, A., Carson, M., \& Román, M. (2011). Together alone: BASIC countries and the climate change conundrum. (pp. 123). Copenhagen, Denmark: Nordic Council of Ministers.

Harris, P. G. (2017). China's Paris pledge on climate change: inadequate and irresponsible. Journal of Environmental Studies and Sciences, 7(1), 102-107.

Hilton, I., \& Kerr, O. (2017). The Paris agreement: China's 'New normal' role in international climate negotiations. Climate Policy, 17(1), 48-58.

Hu, J. (2007). Report at the 17th Party Congress of the Communist Party of China. Retrieved August 14, 2019, from http://www.chinadaily.com.cn/china/200710/24/content_6204564_14.htm 
Hurrell, A. (2012). Emerging powers, North-South relations and global climate politics. International Affairs, 88(3).

ICAP. (2019). China National ETS. International Carbon Action Partnership. ETS Detailed Information. Retrieved August 14, 2019, from

https://icapcarbonaction.com/en/?option=com_etsmap\&task=export\&format=pdf\&layout=list\&s ystems[] $=55$

IEA. (International Energy Agency). (2011). China's per capita emissions match the OECD average in 2035. World Energy Outlook 2011. Retrieved August 14, 2019, from <http://www.climate-change.ch/4DCGI/energie/detail_all?2146>

IEA. (International Energy Agency). (2017). Renewables 2017: Analysis and Forecasts to 2022. [Executive summary]. Retrieved February 3, 2018, from https://www.iea.org/Textbase/npsum/renew2017MRSsum.pdf

IEA. (International Energy Agency). (2018). Global Energy and Co2 Status Report 2017. $\begin{array}{llll}\text { Retrieved } \quad \text { August } & \text { 2019, from }\end{array}$ https://www.iea.org/publications/freepublications/publication/GECO2017.pdf

International Resource Panel. (2019). Global Resources Outlook 2019: Natural Resources for the Future We Want. A Report of the International Resource Panel. Nairobi, Kenya: United Nations Environment Programme.

Intergovernmental Panel on Climate Change. (2014). Climate Change 2014 Synthesis Report. Retrieved August 14, 2019, from https://www.ipcc.ch/report/ar5/syr/.

Intergovernmental Panel on Climate Change. (2018). Global Warming of $1.5^{\circ}$ C. An IPCC Special Report on the impacts of global warming of $1.5^{\circ} \mathrm{C}$ above pre-industrial levels and related global greenhouse gas emission pathways, in the context of strengthening the global response to the 


\section{China and the Arctic environment}

threat of climate change, sustainable development, and efforts to eradicate poverty. Geneva, Switzerland: World Meteorological Organization.

Kallio, J. (2016). Towards China's Strategic Narrative. On the Construction of the HistoricoCultural Roots of China's National Identity in the Light of the Chinese Debate Relating to the Rise of Traditional Schools of Thought [Doctoral dissertation]. Acta Universitatis Lapponiensis, 339.

Kemp, L. (2016). US-Proofing the Paris climate agreement. Climate Policy, 1-16.

Kennedy. (2012). Environmental protests in China on dramatic rise, expert says. SCMP. Retrieved August 14, 2019, from https://www.scmp.com/news/china/article/1072407/environmentalprotests-china-rise-expert-says.

Koch, D., Bauer, S. E., Del Genio, A., Faluvegi, G., McConnell, J. R., Menon, S., ... Shindell, D. (2011). Coupled aerosol-chemistry-climate twentieth-century transient model investigation: Trends in short-lived species and climate responses. Journal of Climate, 24, 2693-2714.

Kopra, S., \& Kauppila, L. (2018). China, fundamental responsibility and Arctic regionalisation. Presented at the International Studies Association Annual Convention, San Francisco, CA.

Kopra, S. (2019). China and great power responsibility for climate change. London, England and New York, NY: Routledge.

Kopra, S. (2020). China, great power responsibility and Arctic security. In L. Heininen \& H. Exner-Pirot (Eds), Climate Change and Arctic Security. Searching for a Paradigm Shift. London, England: Palgrave Pivot.

Korhola, E. (2014). The rise and fall of the Kyoto protocol: Climate change as a political process.

[Academic Dissertation]. Retrieved August 14, 2019, from https://helda.helsinki.fi/bitstream/handle/10138/136507/Therisea.pdf 
Kyoto Protocol. (1998). Kyoto protocol to the United Nations framework convention on climate change. Text of Kyoto Protocol in English, United Nations.

Li, X., Chen, Z., Fan, X., \& Cheng, Z. (2018). Hydropower development situation and prospects in China. Renewable and Sustainable Energy Reviews, 82, 232-239.

Liu, W., Xu, Z., \& Yang, T. (2018). Health effects of air pollution in China. International Journal of Environmental Research and Public Health, 15(7), 1471. doi: 10.3390/ijerph15071471.

Napoli, C. (2012). Understanding Kyoto's failure. SAIS Review, 32(2), 183-196.

National Bureau of Statistics of China. (2019). Statistical communiqué of the People's Republic of China on the 2018 national economic and social development. Retrieved August 14, 2019, from http://www.stats.gov.cn/english/PressRelease/201902/t20190228_1651335.html.

National Development and Reform Commission. (2013). China's Policies and Actions for Addressing Climate Change. Policy Paper. The People's Republic of China. Retrieved August 14, 2019, from http://en.ndrc.gov.cn/newsrelease/201311/P020131108611533042884.pdf

National Development and Reform Commission. (2014). U.S.-China joint statement on climate $\begin{array}{lllll}\text { change. } & \text { Retrieved } & \text { August } & \text { 14, } & \text { from }\end{array}$ http://en.ndrc.gov.cn/newsrelease/201402/t20140218_579304.html

National Development and Reform Commission. (2015). China-U.S. joint Presidential statement on climate change. Retrieved August 14, 2019, from http://en.ndrc.gov.cn/newsrelease/201511/t20151109_757957.html

National Development and Reform Commission. (2016). China-U.S. joint Presidential statement on climate change. Retrieved August 14, 2019, from http://en.ndrc.gov.cn/newsrelease/201604/t20160401_797242.html 
Olivier, J. G. J., Janssens-Maenhout, G., Muntean, M., \& Peters, J. A. H. W. (2015). Trends in global CO2 emissions: 2015 report. Retrieved August 14, 2019, from https://www.pbl.nl/sites/default/files/cms/publicaties/pbl-2015-trends-in-global-co2emisions_2015-report_01803.pdf.

Olivier, J. G. J., \& Peters, J. A. H. W. (2018). Trends in global CO2 and total greenhouse gas emissions: 2018 report. Retrieved August 14, 2019, from https://www.pbl.nl/sites/default/files/cms/publicaties/pbl-2018-trends-in-global-co2-and-totalgreenhouse-gas-emissons-2018-report_3125.pdf.

PAME. (Protection of Arctic Marine Environment). (2019, May 7). Desktop study on marine litter including microplastics in the Arctic. Rovaniemi, Finland: 11th Arctic Council Ministerial Meeting.

Pan, Y. (2006). Evolution of an ecological civilization. Beijing Review, 45. Retrieved August 14, 2019, from http://www.bjreview.cn/EN/06-45-e/point-1.htm

Paris Agreement. (2015). The English text of the Paris agreement. United Nations framework on climate change.

Pike, L., \& Zhe, Y. (2017, December). Five things to know about China's national carbon market. Retrieved August 14, 2019, from https://www.chinadialogue.net/blog/10303-Five-things-toknow-about-China-s-national-carbon-market/en

Rigby, M., Park, S., Saito, T., Western, L. M., Redington, A. L., Fang, X., ... Young, D. (2019). Increase in CFC-11 emissions from eastern China based on atmospheric observations. Nature, 569, 546-550.

Roberts, D. (2016). A global roadmap for climate change action: From COP17 in Durban to COP21 in Paris. South African Journal of Science, 112(5), 9. 
Sahu, B. K. (2018). Wind energy developments and policies in China: A short review. Renewable and Sustainable Energy Review, 81(1), 1393-1405.

Serreze, M. C. (2018). Brave new Arctic. The untold story of the melting North. Princeton, NJ: Princeton University Press.

Shearer, C., Brown, M., \& Buckley, T. (2019, January). China at a crossroads: Continued support for coal power erodes country's clean energy leadership. Institute for Energy Economics and Financial Analysis. Retrieved August 14, 2019, from http://ieefa.org/wpcontent/uploads/2019/01/China-at-a-Crossroads_January-2019.pdf

State Council of the People's Republic of China. (2014, March 5). China declares war against $\begin{array}{lllll}\text { pollution. } & \text { Retrieved } & \text { August } & \text { 14, 2019, } & \text { from }\end{array}$ http://english.gov.cn/premier/news/2014/08/23/content_281474983008687.htm

State Council of the People's Republic of China. (2015, May 8) 国务院兊于印发《中国制造 2025》的通知 (Announcement on the publication of 'Made in China 2025' report). Retrieved August 14, 2019, from http://www.gov.cn/zhengce/content/2015-05/19/content_9784.htm

State Council of the People's Republic of China. (2018). China's Arctic Policy. Retrieved August 14 , 2019 , from http://english.gov.cn/archive/white_paper/2018/01/26/content_281476026660336.htm

State Council Information Office of the People's Republic of China. (2018). China's Arctic policy. Retrieved August 14, 2019 , from http://english.gov.cn/archive/white_paper/2018/01/26/content_281476026660336.htm

Syri, S., Vihma, A., Airaksinen, M., Hast A., Järvelä, M., Ollikainen, M., ... Soimakallio, S. (2013). Suomen ilmastopaneeli: Kansainvälisen ja EU:n ilmastopolitiikan ajankohtaisia teemoja. [Report] Suomen Ilmastopaneeli, Raportti (6th ed.). Retrieved August 14, 2019, from http://www.ilmastopaneeli.fi/uploads/selvitykset_lausunnot/ilmastopaneelin_raportti6.pdf 
The 18th National Congress of the Communist Party of China. (2012). Constitution of the CCP (revised). Retrieved August 14, 2019, from http://www.china.org.cn/chinese/18da/201211/19/content_27156212_2.htm

Travnikov, O. (2005). Contribution of the intercontinental atmospheric transport to mercury pollution in the Northern Hemisphere. Atmospheric Environment, 39, 7541.

UNEP. (2015). The climate and environmental benefits of controlling SLCPs in P.R. China. Nairobi, Kenya: UN Environment Programme.

UNEP. (2018). Global Mercury Assessment 2018. Geneva, Switzerland: UN Environment $\begin{array}{lllll}\text { Programme. } & \text { Retrieved } & \text { May } & 2019, & \text { from }\end{array}$ https://wedocs.unep.org/bitstream/handle/20.500.11822/27579/GMA2018.pdf?sequence=1\&isAl lowed=y

UNFCCC. (2019). United Nations framework convention on climate change. United Nations. Retrieved August 14, 2019, from http://unfccc.int/2860.php

UNFCCC INDC Submission Portal. (2019). INDC submissions of Parties. United Nations. Retrieved August 14, 2019, from http://www4.unfccc.int/submissions/indc/Submission\%20Pages/submissions.aspx

U.S. Geological Survey. (2008). Circum-Arctic resource appraisal: Estimates of undiscovered oil and gas north of the Arctic Circle. U.S. Department of the Interior. Retrieved August 14, 2019, from http://pubs.usgs.gov/fs/2008/3049/fs2008-3049.pdf.

Wang, H-J., Chen, H-P., \& Liu, J. (2015). Arctic sea ice decline intensified haze pollution in Eastern China. Atmospheric and Oceanic Science Letters, 8(1), 1-9.

Woon, C. Y. (2018). China's contingencies: Critical geopolitics, Chinese exceptionalism and the uses of history. Geopolitics, 23(1), 67-95. 
World Bank. (2019). Data. Manufacturing, value added (\% of GDP). Retrieved from https://data.worldbank.org/indicator/nv.ind.manf.zs

World Nuclear Association. (2019). Nuclear power in China. Retrieved May 24, 2019, from http://www.world-nuclear.org/information-library/country-profiles/countries-a-f/china-nuclearpower.aspx.

$\mathrm{Xi}, \mathrm{J}$. (2017). Secure a decisive victory in building a moderately prosperous society in all respects and strive for the great success of socialism with Chinese characteristics for a new era. Retrieved August 14, 2019, from http://www.xinhuanet.com/english/download/Xi_Jinping's_report_at_19th_CPC_National_Cong ress.pdf.

Xinhua. (2019). Natural gas consumption surges in China in 2018. Retrieved August 14, 2019, from http://www.xinhuanet.com/english/2019-02/04/c_137798876.htm.

Yamineva, Y., \& Kulovesi, K. (2018). Keeping the Arctic white: The legal and governance landscape for reducing short-lived climate pollutants in the Arctic region. Transnational Environmental Law, 7(2), 201-227.

Yamineva, Y., \& Liu, Z. (2019). Cleaning the air, protecting the climate: Policy, legal and institutional nexus to reduce black carbon emissions in China. Environmental Science and Policy, 95 (May), 1-10.

Yao, B., Ross, K., Zhu, J., Igusky, K., Song, R., \& Damassa, T. (2016). Opportunities to enhance non-carbon dioxide greenhouse gas mitigation in China. [Working Paper]. Washington, DC: World Resources Institute. Retrieved August 14, 2019, from http://www.wri.org/publication/greenhouse-gasmitigation-in-china. 
Zhang, D., Wang, J., Yonggang, L., Si, Y., Huang, C., Yang, J., ... Li, W. (2017). Present situation and future prospect of renewable energy in China. Renewable and Sustainable Energy Reviews, $76,865-871$.

Zhang, M. (2015, October 17). China in the Arctic - Practices and policies, China country session. [Keynote speech]. Iceland, Reykjavik. Retrieved August 14, 2019, from https://www.fmprc.gov.cn/mfa_eng/wjbxw/t1306858.shtml.

Zheng, B., Zhang, Q., Borken-Kleefeld, J., Huo, H., Guan, D., Klimont, Z., .. He, K. (2015). How will greenhouse gas emissions from motor vehicles be constrained in China around 2030?. Applied Energy, 156, 230-240.

Zheng, B., Tong, D., Li, M., Liu, F., Hong, C., Geng, G., ... Zhang, Q. (2018). Trends in China's anthropogenic emissions since 2010 as the consequence of clean air actions. Atmos. Chem. Phys., 18, 14095-14111. doi.org/10.5194/acp-18-14095-2018 